\title{
Adult-onset Kawasaki disease (mucocutaneous lymph node syndrome) and concurrent Coxsackievirus A4 infection: a case report
}

This article was published in the following Dove Press journal:

International Medical Case Reports Journal

29 September 2015

Number of times this article has been viewed

Yuki Ueda'

Tsuneaki Kenzaka ${ }^{1,2}$

Ayako Noda'

Yu Yamamoto'

Masami Matsumura'

'Division of General Internal

Medicine, Jichi Medical University

Hospital, Shimotsuke, ${ }^{2}$ Division of

Community Medicine and Career

Development, Kobe University

Graduate School of Medicine, Japan
Correspondence: Tsuneaki Kenzaka Division of Community Medicine and Career Development, Kobe University Graduate School of Medicine,

2-I-5, Arata-cho, Hyogo-ku,

Kobe 652-0032, Hyogo, Japan

Tel +81783826732

Fax +81783826283

Email smile.kenzaka@jichi.ac.jp
Introduction: Kawasaki disease (KD) most commonly develops in infants, although its specific cause is still unclear. We report here a rare case of adult-onset KD which revealed to be concurrently infected by Coxsackievirus A4.

Case presentation: The patient was a 37-year-old Japanese man who presented with fever, exanthema, changes in the peripheral extremities, bilateral non-exudative conjunctival injection, and changes in the oropharynx, signs that meet the diagnostic criteria for KD defined by the Centers for Disease Control and Prevention. In this case, the patient had a significantly high antibody titer for Coxsackievirus A4, which led us to presume that the occurrence of KD was concurrent Coxsackievirus A4 infection.

Conclusion: We reported a very rare case of $\mathrm{KD}$ which suggests that the disease can be concurrent Coxsackievirus A4 infection. Although KD is an acute childhood disease, with fever as one of the principal features, KD should also be considered in the differential diagnosis when adult patients present with a fever of unknown cause associated with a rash.

Keywords: adult-onset, Coxsackievirus A4, Kawasaki disease, mucocutaneous lymph node syndrome, skin rash

\section{Introduction}

Kawasaki disease (KD) or mucocutaneous lymph node syndrome is a childhood disorder that was first reported by Tomisaku Kawasaki in $1967 .{ }^{1}$ The characteristic signs are conjunctival congestion, skin rash, skin desquamation of the peripheral limbs, erythema of the oral cavity, lips, and palms, and cervical lymphadenopathy. ${ }^{1}$ KD most commonly develops in infants. Approximately $85 \%$ of the patients with KD are under 5 years of age. ${ }^{2,3}$ The occurrence of $\mathrm{KD}$ is rare in adolescents and adults. ${ }^{4}$ The specific cause of KD is still unclear, but some reports suggest that it is triggered by bacterial or viral infections. ${ }^{5-7}$ Herein, we describe a rare case of adult-onset KD which revealed to be concurrently infected by Coxsackievirus A4.

\section{Case presentation}

The patient consented to his case being included in this case report. Institutional Review Board approval was not deemed necessary for the following retrospective case report. All principles outlined in the Declaration of Helsinki were followed. A 37-yearold, previously healthy Japanese man was admitted to our hospital 12 days after he developed a fever of $38^{\circ} \mathrm{C}$ and erythema of the hands, arms, and legs. Concurrently, he developed swollen and painful fingers. Two days later, he consulted the outpatient department because of fever. He was treated with $300 \mathrm{mg}$ /day of cefcapene-pivoxil and 
$60 \mathrm{mg}$ /day of loxoprofen, but his condition did not improve. Seven days before admission to our hospital, he was admitted to another hospital for examination of the cause of the fever and erythema in the neck, abdomen, back, and legs. The laboratory test results in the previous hospital included total bilirubin of $3.58 \mathrm{mg} / \mathrm{dL}$, aspartate aminotransferase of $48 \mathrm{U} / \mathrm{L}$, alanine aminotransferase of $61 \mathrm{U} / \mathrm{L}, \gamma$-glutamyltranspeptidase of $116 \mathrm{U} / \mathrm{L}$, blood nitrogen urea of $45 \mathrm{mg} / \mathrm{dL}$, and creatinine of $3.45 \mathrm{mg} / \mathrm{dL}$, indicating liver and kidney dysfunction. On the 2 nd day in the previous hospital, he developed conjunctival congestion. On day 5, desquamation of the hands, fingers, and toes was noted. He was eventually referred to our hospital for close examination and treatment.

At the time of admission to our hospital, the patient was clearly conscious. His temperature was $37.7^{\circ} \mathrm{C}$, blood pressure was $136 / 84 \mathrm{mmHg}$, pulse rate was regular at 88 beats per minute, and respiratory rate was 28 breaths per minute. Physical examination showed desquamation around the lips (Figure 1A), fingers (Figure 1B), and feet (Figure 1C). Edematous erythema was noted on his trunk, extremities, axillae, flank, and hip. There was also brawny edema of the hands and feet and marked congestion of the conjunctivae (Figure 1D). His lips were reddish, dry, and swollen. His palatine tonsils were also slightly red. The cervical lymph nodes were not enlarged. The chest was clear to auscultation. The abdomen was soft and non-tender. No arthritis was noted, and neurological examination also yielded normal results. Laboratory data on admission revealed leukocytosis, neutrophilia, and thrombocytosis, and serum aspartate aminotransferase, alanine aminotransferase, creatinine, and C-reactive protein levels were elevated (Table 1). Repeat blood culture was sterile. Rapid test for Streptococcus pyogenes antigen was negative. The presence of antibodies to Epstein-Barr virus and cytomegalovirus indicated past infections (Table 2). Chest radiography showed no abnormalities.
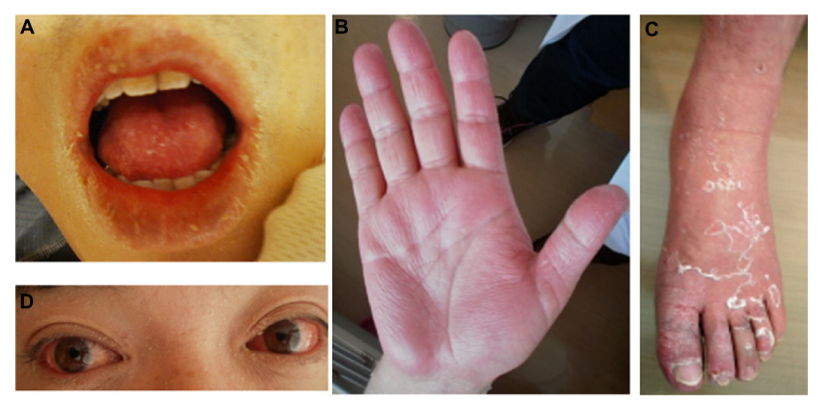

Figure I Desquamation around the (A) lips, (B) fingers, and (C) feet, and (D) bilateral non-exudative conjunctival injection.

Note: At the time of admission to our hospital, physical examination showed desquamation around the lips, fingers, and feet, and his conjunctivae were markedly congested.
Table I Laboratory data at the time of admission to our hospital (day 13 of illness)

\begin{tabular}{lll}
\hline Parameter & Recorded value & Standard value \\
\hline White blood cell count & $24.40 \times 10^{9} / \mathrm{L}$ & $4.00-7.50 \times 10^{9} / \mathrm{L}$ \\
Myelocyte & $0.73 \times 10^{9} / \mathrm{L}$ & \\
Metamyelocyte & $0.12 \times 10^{9} / \mathrm{L}$ & \\
Stab neutrophil & $3.90 \times 10^{9} / \mathrm{L}$ & \\
Segmented neutrophil & $15.6 \times 10^{9} / \mathrm{L}$ & \\
Eosinophil & $1.59 \times 10^{9} / \mathrm{L}$ & \\
Monocyte & $1.46 \times 10^{9} / \mathrm{L}$ & \\
Lymphocyte & $0.98 \times 10^{9} / \mathrm{L}$ & \\
Erythroblast & $0.24 \times 10^{9} / \mathrm{L}$ & \\
Hemoglobin & $11.5 \mathrm{~g} / \mathrm{dL}$ & $11.3-15.2 \mathrm{~g} / \mathrm{dL}$ \\
Hematocrit & $35.8 \%$ & $36 \%-45 \%$ \\
Platelet & $411 \times 10^{9} / \mathrm{L}$ & $130-350 \times 10^{9} / \mathrm{L}$ \\
C-reactive protein & $14.02 \mathrm{mg} / \mathrm{dL}$ & $\leqq 0.14 \mathrm{mg} / \mathrm{dL}$ \\
Total protein & $6.8 \mathrm{~g} / \mathrm{dL}$ & $6.9-8.4 \mathrm{~g} / \mathrm{dL}$ \\
Albumin & $2.5 \mathrm{~g} / \mathrm{dL}$ & $3.9-5.1 \mathrm{~g} / \mathrm{dL}$ \\
Total bilirubin & $3.58 \mathrm{mg} / \mathrm{dL}$ & $0.4-1.5 \mathrm{mg} / \mathrm{dL}$ \\
Direct bilirubin & $2.34 \mathrm{mg} / \mathrm{dL}$ & $0.06-0.23 \mathrm{mg} / \mathrm{dL}$ \\
Aspartate aminotransferase & $48 \mathrm{U} / \mathrm{L}$ & $1 \mathrm{I}-30 \mathrm{U} / \mathrm{L}$ \\
Alanine aminotransferase & $61 \mathrm{U} / \mathrm{L}$ & $4-30 \mathrm{U} / \mathrm{L}$ \\
Lactate dehydrogenase & $360 \mathrm{U} / \mathrm{L}$ & $109-216 \mathrm{U} / \mathrm{L}$ \\
Alkaline phosphatase & $590 \mathrm{U} / \mathrm{L}$ & $107-330 \mathrm{U} / \mathrm{L}$ \\
$\gamma$-Glutamyltranspeptidase & $116 \mathrm{U} / \mathrm{L}$ & $<70 \mathrm{U} / \mathrm{L}$ \\
Cholinesterase & $186 \mathrm{U} / \mathrm{L}$ & $209-504 \mathrm{U} / \mathrm{L}$ \\
Blood nitrogen urea & $45 \mathrm{mg} / \mathrm{dL}$ & $8-20 \mathrm{mg} / \mathrm{dL}$ \\
Creatinine & $3.45 \mathrm{mg} / \mathrm{dL}$ & $0.63-1.03 \mathrm{mg} / \mathrm{dL}$ \\
Sodium & $138 \mathrm{mEq} / \mathrm{L}$ & $136-148 \mathrm{mEq} / \mathrm{L}$ \\
Potassium & $4.2 \mathrm{mEg} / \mathrm{L}$ & $3.6-5.0 \mathrm{mEq} / \mathrm{L}$ \\
Glucose & $113 \mathrm{mg} / \mathrm{dL}$ & $70-109 \mathrm{mg} / \mathrm{dL}$ \\
\hline & & \\
& & \\
& &
\end{tabular}

Computed tomography of the chest and abdomen revealed hepatic and splenic enlargement and fatty liver. A skin biopsy of the erythema on the left forearm showed lymphocyte infiltrations around vessels in the superficial layer of the epidermis. There were no findings suspected for vasculitis or drug allergy. The patient had fever for $>5$ days, and four additional principal signs indicative of KD based on the diagnostic criteria defined by the Centers for Disease Control and Prevention, ${ }^{8}$ namely exanthema, change in peripheral extremities, bilateral non-exudative conjunctival injection, and changes in the oropharynx, on the basis of which he was clinically diagnosed with $\mathrm{KD}$. On the day of admission, he was treated with $2,700 \mathrm{mg} /$ day of oral aspirin $(30 \mathrm{mg} / \mathrm{kg} /$ day). On day 4, the dose of aspirin was reduced to $450 \mathrm{mg}$ /day $(5 \mathrm{mg} / \mathrm{kg} /$ day) because of defervescence; however, on day 5 , the patient developed liver dysfunction as an adverse effect of aspirin. After day 6 in our hospital, the myalgia, congested conjunctivae, erythema, and desquamations were found to be gradually resolving. By day 13, the erythema and desquamation were completely resolved. However, the treatment was switched from aspirin to $200 \mathrm{mg} /$ day of cilostazol because 
Table 2 Microbiological data

\begin{tabular}{|c|c|c|}
\hline Parameter & $\begin{array}{l}\text { Recorded } \\
\text { value }\end{array}$ & $\begin{array}{l}\text { Standard } \\
\text { value }\end{array}$ \\
\hline Bacterial blood culture (three sets) & Negative & Negative \\
\hline Anti-streptolysin O (LA) & $95 \mathrm{U} / \mathrm{mL}$ & $<186 \mathrm{U} / \mathrm{mL}$ \\
\hline Anti-streptokinase (PA) & 80 & $<\mathrm{I}, 280$ \\
\hline $\begin{array}{l}\text { Streptococcal pharyngitis direct antigen } \\
\text { test (IC) }\end{array}$ & Negative & Negative \\
\hline $\begin{array}{l}\text { Epstein-Barr virus, viral capsid antigen } \\
\text { antibody, IgG (FAT) }\end{array}$ & 80 & $<10$ \\
\hline $\begin{array}{l}\text { Epstein-Barr virus, viral capsid antigen } \\
\text { antibody, IgM (FAT) }\end{array}$ & $<10$ & $<10$ \\
\hline $\begin{array}{l}\text { Epstein-Barr virus, nuclear antigen } \\
\text { antibody (FAT) }\end{array}$ & 40 & $<10$ \\
\hline Cytomegalovirus antibody, IgG (EIA) & 3,800 & - \\
\hline Cytomegalovirus antibody, IgM (EIA) & - & - \\
\hline Herpes simplex virus antibody, IgG (EIA) & 22,000 & - \\
\hline Herpes simplex virus antibody, IgM (EIA) & 1.3 & - \\
\hline Measles virus antibody, IgG (EIA) & 440 & - \\
\hline Measles virus antibody, IgM (EIA) & - & - \\
\hline Parvovirus BI9 antibody, IgM (EIA) & 0.27 & $<0.80$ \\
\hline $\begin{array}{l}\text { Human immunodeficiency virus antigen } \\
\text { and antibody (CLIA) }\end{array}$ & - & - \\
\hline
\end{tabular}

Abbreviations: LA, latex agglutination; PA, particle agglutination; IC, immunochromatography; FAT, fluorescence antibody technique; EIA, enzyme immunoassay; CLIA, chemiluminescent immunoassay.

the alanine aminotransferase levels increased to $150 \mathrm{U} / \mathrm{L}$ (Figure 2). Subsequently, the liver function normalized, and the patient was discharged on the 13th hospital day. During hospitalization, transthoracic echocardiography disclosed no coronary aneurysms. At follow-up, coronary computed tomography performed 2 months after the onset of the disease revealed no coronary aneurysms (Figure 3 ).
Assuming that a viral infection was associated with KD in this patient, we examined the antibody titers in response to viruses that cause acute eruptive diseases. The virus neutralization test was used to determine antibody titers for Coxsackievirus, adenovirus, and echovirus in the serum, on days 5, 13, and 32 from onset of the disease. Antibody titer of Coxsackievirus A4 on day 13 was fourfold higher than that on day 5 and decreased on day 32 in the following sequence: 32 -fold on day 5, 128-fold on day 13 , and 32 -fold on day 32 (Table 3 ). These results strongly suggest that the Coxsackievirus infection was present when KD occurred.

\section{Discussion Epidemiology}

Here, we describe a case of adult-onset KD which revealed to be concurrently infected by Coxsackievirus A4. Adult-onset $\mathrm{KD}$ is rare, and this is a very rare case of $\mathrm{KD}$ and concurrent Coxsackievirus A4 infection.

KD most commonly develops in infants. The annual incidence is 67 cases per 100,000 children in Japan and 5.6 cases per 100,000 children in the USA. Children under 5 years of age constitute $88.5 \%$ of reported cases. ${ }^{2,3} \mathrm{KD}$ occurs predominantly in children while rarely in adolescents and adults. ${ }^{4}$ The oldest reported case was that of a 68 -year-old Caucasian man from France in $2005 .{ }^{9}$ The diagnostic criteria for KD as defined by the Centers for Disease Control and Prevention include unexplained fever lasting 5 days or more and at least four out of the five following criteria: 1) polymorphic exanthema; 2) changes in the peripheral extremities, that is, erythema

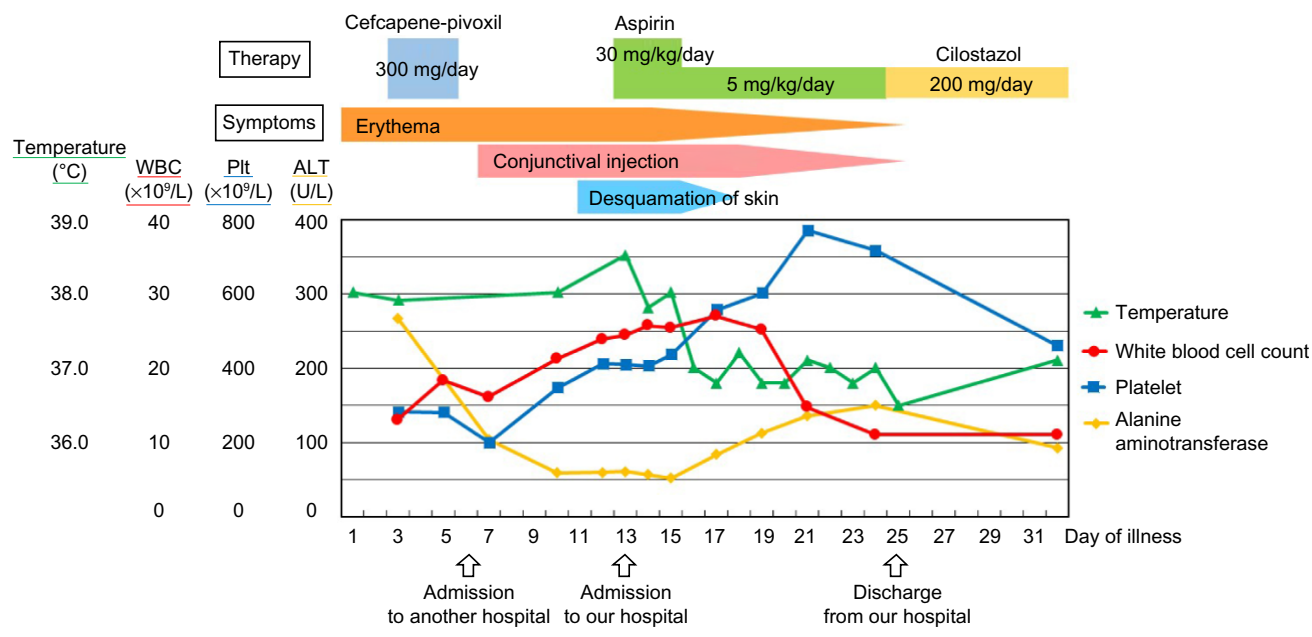

Figure 2 Clinical course.

Notes: On the day of admission to our hospital, he was treated with $30 \mathrm{mg} / \mathrm{kg} / \mathrm{day}$ of oral aspirin. On day 4 , the dose of aspirin was reduced to $5 \mathrm{mg} / \mathrm{kg} / \mathrm{day}$ because of defervescence. After day 6 in our hospital, the myalgia, congested conjunctivae, erythema, and desquamations gradually resolved. By day 13 , the erythema and desquamation were completely resolved. However, the treatment was switched from aspirin to $200 \mathrm{mg} /$ day of cilostazol because of liver dysfunction as an adverse effect of aspirin. Abbreviations: WBC, White blood cell count; Plt, Platelet; ALT, Alanine aminotransferase. 


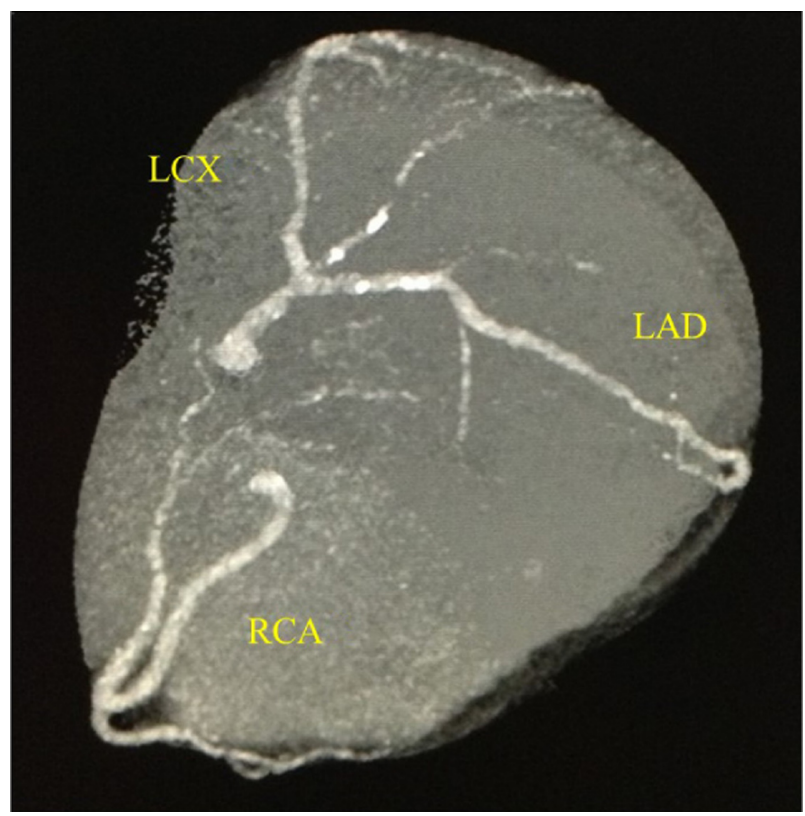

Figure 3 Coronary computed tomography.

Note: The coronary computed tomography that was performed 2 months after the onset of the disease revealed no coronary aneurysms.

Abbreviations: LCX, left circumflex artery; LAD, left anterior descending coronary artery; RCA, right coronary artery.

and/or indurative edema of the palms and soles (acute phase) or desquamation around the finger tips (convalescent phase); 3) bilateral non-exudative conjunctival injection; 4) changes in the oropharynx, that is, injected or fissured lips, strawberry tongue, and injected pharynx; and 5) acute nonsuppurative cervical lymphadenopathy $(>1.5 \mathrm{~cm}$ in diameter). Patients with fewer than four of these clinical signs can be diagnosed as having atypical KD if coronary artery

Table 3 Viral antibody titers

\begin{tabular}{llllll}
\hline Virus & Type & Method & Day 5 & Day I4 & Day 32 \\
\hline Adenovirus & 2 & NT & 64 & 32 & 64 \\
& 3 & NT & $<4$ & 4 & 16 \\
Coxsackievirus & 4 & NT & - & $<4$ & - \\
& A2 & NT & - & 8 & - \\
& A3 & NT & - & 4 & - \\
& A4 & NT & $\mathbf{3 2}$ & $\mathbf{I 2 8}$ & 32 \\
& A5 & NT & - & 4 & - \\
& BI & NT & - & 8 & - \\
& B2 & NT & 32 & 32 & 64 \\
& B3 & NT & 4 & 16 & 8 \\
& B4 & NT & 64 & 64 & 128 \\
& I & NT & - & $<4$ & - \\
& 3 & NT & 64 & 128 & 128 \\
& 5 & NT & - & $<4$ & - \\
& 7 & NT & 8 & 16 & 16 \\
\hline
\end{tabular}

Notes: The bold font indicates the antibody titer of only Coxsackievirus A4 showed significant change. The antibody titer of only Coxsackievirus A4 was increased fourfold on day 13 as compared to day 5 and was decreased on day 32.

Abbreviation: NT, neutralization. abnormalities are present. ${ }^{8}$ Additionally, it is necessary to exclude the possibility of other diseases that cause fever and rash (eg, toxic shock syndrome, streptococcal scarlet fever, measles, other viral infections, Stevens-Johnson syndrome, or a drug reaction).

Desquamation is typically found during the convalescent phase. However, in patients who develop KD in adulthood, the time of onset of desquamation is varied. Some of these patients have been reported to develop desquamation during the acute phase of KD with fever., ${ }^{9} 10$ This may be associated with the fact that multiple factors cause KD and that the mechanism of KD differs between adults and children. In our patient, desquamation appeared relatively early and then improved. Although the side effects of cefcapene-pivoxil and loxoprofen should be considered in the differential diagnosis, both drugs were used without adverse effects in this patient before this episode. Item (2) in the diagnostic criteria was satisfied even if desquamation was excluded. Therefore, desquamation does not affect the diagnosis.

\section{Etiology}

The etiology of KD remains unclear, although the clinical features suggest that a viral or bacterial infection may be a trigger. ${ }^{11} \mathrm{KD}$ has features similar to those of other childhood infectious diseases. For example, similar to measles and adenovirus infection, KD has the clinical features of fever and rash. The epidemiological features including age distribution, seasonal prevalence, and occurrence of community outbreaks with geographical spread also suggest a transmissible childhood disease. ${ }^{12}$ However, an infectious agent has not yet been identified. Adenovirus, herpesvirus, Epstein-Barr virus, human coronavirus New Haven, measles virus, rotavirus, dengue virus, and retrovirus are putative etiological agents of KD. These are commonly found pathogens. ${ }^{13}$ However, the reason why only some patients infected with these viruses develop KD is unknown. A report demonstrated coinfection with Coxsackievirus B3 in a patient with $\mathrm{KD} .{ }^{13}$

\section{Clinical findings}

In our patient, we examined the antibody titers of viruses that cause an acute eruptive disease, such as Coxsackievirus (types A2-A5, B1-B4), adenovirus (types 2-4), echovirus (types 1, 3, 5, 7), herpes simplex virus, Epstein-Barr virus, cytomegalovirus, human immunodeficiency virus, and human parvovirus. We analyzed serum samples taken on days 5,13 , and 32 of illness for antibody titers of Coxsackievirus, adenovirus, and echovirus. The day 5 serum sample was taken from the previous hospital. The antibody titer of only Coxsackievirus 
A4 was increased fourfold on day 13 as compared to day 5 and was decreased on day 32 . This strongly suggests that the Coxsackievirus infection was present when KD occurred. Coxsackievirus A4 is a member of the Picornaviridae family of viruses in the Enterovirus genus. It can be a cause of herpangina and myocarditis. Rigante et al reported the cases of Kawasaki syndrome and concurrent Coxsackievirus B3 infection. ${ }^{13}$ However, to the best of our knowledge, there have been no reports of KD cases and concurrent Coxsackievirus A4 infection thus far. There are various types of adenovirus and Coxsackievirus, and tests for proving these common viral infections (eg, serological antibody, polymerase chain reaction) are performed in few cases. Therefore, such coinfections remain undiagnosed and are thus likely unreported.

\section{Treatment}

It is important not only to manage symptoms in the acute phase of KD but also to prevent the cardiovascular after-effects. There are three essential treatments for KD: 1) intravenous immunoglobulin (IVIG) to obtain an anti-inflammatory effect, 2) aspirin for anti-inflammatory and antiplatelet effects, and 3) management of any complications (eg, meningitis or disseminated intravascular coagulation). IVIG can mitigate inflammation and the coronary artery complications. A dose of $2 \mathrm{~g} / \mathrm{kg}$ of IVIG in a single infusion has been found to be effective. This therapy should be initiated within the first 10 days of illness. ${ }^{14,15}$ IVIG has not been demonstrated to be effective if administered after the first 10 days of illness. Furthermore, one report has noted a risk of unfavorable effects with IVIG regarding cardiac sequelae if IVIG is started on day 9 or later. ${ }^{16}$ In our patient, IVIG was not administered because he was admitted to our hospital on the 13th day of illness.

Aspirin is often administered with IVIG in patients with KD. In the acute phase, the American Heart Association recommends high-dose aspirin (80-100 mg/kg/day) to achieve an anti-inflammatory effect. ${ }^{14}$ However, it is not clear if a higher dose would be more effective than the lower dose (30-50 mg/ $\mathrm{kg}$ /day). ${ }^{17}$ When the patient remains afebrile for 48-72 hours, the aspirin dose is lowered ( $3-5 \mathrm{mg} / \mathrm{kg} /$ day) and maintained to achieve an antiplatelet effect until the patient shows no evidence of coronary changes for 6-8 weeks after onset. ${ }^{14}$ In addition, regular echocardiographic evaluation should be performed to assess for the possibility of coronary artery aneurysm.

In our patient, $30 \mathrm{mg} / \mathrm{kg} /$ day of aspirin was used to achieve an anti-inflammatory effect from day 13 to day 15 of illness to ensure better tolerance to gastrointestinal and other side effects. The dose of aspirin was reduced to $5 \mathrm{mg} / \mathrm{kg} /$ day on day 16 of illness. Because the patient developed liver dysfunction as an adverse effect of aspirin on day 5 , the treatment was switched to $200 \mathrm{mg}$ /day of cilostazol on day 13 .

It is still unclear if the treatment for KD in adults should be the same as in infants, especially with regard to the dose and duration of IVIG and aspirin administration.

\section{Conclusion}

This rare case of adult-onset KD suggests that the disease can be concurrent Coxsackievirus A4 infection. Although KD is an acute childhood disease, with fever as the main sign, it should be considered in the differential diagnosis also when adult patients present with unexplained fever and a rash.

\section{Author contributions}

Yuki Ueda contributed to manuscript editing. Tsuneaki Kenzaka contributed to management of the case, and manuscript editing and correction. Ayako Noda and Yu Yamamoto contributed to clinical management of the case and revision of the manuscript. Masami Matsumura contributed to manuscript correction and editing of the captions for the illustrations. All the authors read and approved the final version of the manuscript. All authors contributed toward data analysis, drafting and critically revising the paper and agree to be accountable for all aspects of the work.

\section{Disclosure}

The authors declare that they have no conflicts of interest related to this work.

\section{References}

1. Kawasaki T. Acute febrile muco-cutaneous lymph node syndrome in young children with unique digital desquamation. Jpn J Allergol. 1967; 16:178-222.

2. Yanagawa H, Kawasaki T, Shigematsu I. Nationwide survey on Kawasaki disease in Japan. Pediatrics. 1987;80:58-62.

3. Rauch AM. Kawasaki syndrome: critical review of US epidemiology. Prog Clin Biol Res. 1987;250:33-40.

4. Jackson JL, Kunkel MR, Libow L, Gates RH. Adult Kawasaki disease. Report of two cases treated with intravenous gamma globulin. Arch Intern Med. 1994;154:1398-1405.

5. Hall M, Hoyt L, Ferrieri P, Schlievert PM, Jenson HB. Kawasaki syndrome-like illness associated with infection caused by enterotoxin B-secreting Staphylococcus aureus. Clin Infect Dis. 1999;29:586-589.

6. Matsubara K, Fukaya T, Miwa K, et al. Development of serum IgM antibodies against super antigens of Staphylococcus aureus and Streptococcus pyogenes in Kawasaki disease. Clin Exp Immunol. 2006;143:427-434.

7. Esper F, Shapiro ED, Weibel C, Ferguson D, Landry ML, Kahn JS Association between a novel human coronavirus and Kawasaki disease. J Infect Dis. 2005;191:499-502.

8. Pascal S, Katia S, Amar S, Denis VD, Guillaume M, Christiane B. Adult Kawasaki disease: report of two cases and literature review. Semin Arthritis Rheum. 2005;34:785-792.

9. Rauch AM, Hurwitz ES. Center for Disease Control (CDC) case definition for Kawasaki syndrome. Pediatr Infect Dis. 1985;4:702-703. 
10. Gomard-Mennesson E, Landron C, Dauphin C, et al. Kawasaki disease in adults: report of 10 cases. Medicine (Baltimore). 2010;89(3): 149-158.

11. Principi N, Rigante D, Esposito S. The role of infection in Kawasaki syndrome. J Infect. 2013;67:1-10.

12. Burns JC, Cayan DR, Tong G, et al. Seasonality and temporal clustering of Kawasaki syndrome. Epidemiology. 2005;16:220-225.

13. Rigante D, Cantarini L, Piastra M, et al. Kawasaki syndrome and concurrent Coxsackie virus B3 infection. Rheumatol Int. 2012;32: 4037-4040.

14. Newburger JW, Takahashi M, Gerber MA, et al. Diagnosis, treatment, and long-term management of Kawasaki disease: a statement for health professionals from the Committee on Rheumatic Fever, Endocarditis, and Kawasaki Disease, Council on Cardiovascular Disease in the Young, American Heart Association. Pediatrics. 2004;114:1708-1733.
15. Dajani AS, Taubert KA, Gerber MA, et al. Diagnosis and therapy of Kawasaki disease in children. Circulation. 1993;87:1776-1780.

16. Yanagawa H, Nakamura Y, Sakata K, Yashiro M. Use of intravenous $\gamma$-globulin for Kawasaki disease: effects on cardiac sequelae. Pediatr Cardiol. 1997;18:19-23.

17. Brogan PA, Bose A, Burgner D, et al. Kawasaki disease: an evidence based approach to diagnosis, treatment, and proposals for future research. Arch Dis Child. 2002;86:286-290.

\section{Publish your work in this journal}

The International Medical Case Reports Journal is an international, peer-reviewed open-access journal publishing original case reports from all medical specialties. Previously unpublished medical posters are also accepted relating to any area of clinical or preclinical science. Submissions should not normally exceed 2,000 words or
4 published pages including figures, diagrams and references. The manuscript management system is completely online and includes a very quick and fair peer-review system, which is all easy to use. Visit http://www.dovepress.com/testimonials.php to read real quotes from published authors.

Submit your manuscript here: http://www.dovepress.com/international-medical-case-reports-journal-journal 